Francis J. Thomson

\title{
ABERCIUS, THE PRINCIPAL SCRIBE OF THE HILANDAR MENOLOGIUM, THE LARGEST EXTANT SOUTH SLAV MENOLOGIUM
}

Between 1622/3 and 1625/6 a menologium was copied in eight volumes, six of them by Abercius, a monk of Hilandar, while the other two were copied by an anonymous scribe. In addition to these six codices Abercius copied ten or possibly eleven other manuscripts. Virtually all that is known about him is what he himself wrote in the colophons of his manuscripts.

1. The first codex is a panegyricon for the months of September to December, now codex 54 in the Museum of the Serbian Orthodox Church at Belgrade. At the end of the manuscript is a text of seven lines, each containing a somewhat banal gnome, which is followed by the colophon that begins by pointing out that the seven lines reveal the name of the scribe of the codex and indeed the initial letters of the lines form the acrostic $\hat{A} \hat{A} \AA ̊ 円 \hat{E}_{s} \neg$, viz. his name was Abercius. In the colophon he writes that he copied the manuscript in 7123 (1614/5) as a gift for the monastery of the Annunciation at Dobrun, near Višegrad in south-eastern Bosnia, when Habakkuk was abbot.

2. The next manuscript contained a triodion and was codex 1349 in the collection of the Serbian National Library at Belgrade, which was destroyed in an air raid in the night of 6-7 April 1941, although prior to that the colophon preceded by the same seven gnomes as in the first codex had been published. The colophon reveals that he copied the manuscript in $7124(1615 / 6)$ at the monastery of St Nicholas, one of several small monasteries in the Ovčar gorge.

3. The third manuscript is a psalter with an abridged octoechus, a combination known in Slavonic as а слідованна- lалтирь, which was copied by five scribes, now codex Q.I.90 in the Russian National Library at St Petersburg. Abercius copied ff. $3^{\mathrm{r}}-114^{\mathrm{r}}, 138^{\mathrm{r}}-161^{\mathrm{v}}$ and $228^{\mathrm{r}}-291^{\mathrm{r}}$ including the colophon, which reveals that it had been copied in a cave above the Studenica river in 7126 (1617/8), viz. in the hermitage of St Sabas of Serbia near the monastery of the Deipara Euergetis by the Studenica, where he also copied the next two manuscripts.

4. Codex IX.H.8 in the National Museum at Prague is a florilegium copied by no fewer than ten scribes and is a composite manuscript with folia of the $16^{\text {th }}, 17^{\text {th }}$ and $18^{\text {th }}$ centuries. Abercius copied the major part of the codex, viz. ff. $1^{\mathrm{r}}-74^{\mathrm{r}}$ and $79^{\mathrm{r}}-117^{\mathrm{r}}$, in the hermitage of St Sabas in 7127 (1618/9). His folia contain the typicon of the monastery by the Studenica, the vita of Despot Stephen Nemanja of Serbia, in religion Symeon, by his son Rastko, in religion Sabas, and two minor entries. Historically speaking, this codex is the most important of Abercius' manuscripts as it is the best witness to the Studenica typicon and also the sole witness to the complete text of Sabas' vita of his Symeon.

5-7. Codices 436-438 in the collection of Hilandar contain a synaxarium for the entire year and the colophon in the final volume for March to August reveals that Abercius had moved to the hermitage of St Sabas, a dependency of Hilandar, at Karyes on Athos, where he had copied the three manuscripts in the course of 7129 (1620/1). He remained at the hermitage for at least the next twelve years, during which time he copied twelve manuscripts between 1620/1 and 1632/3. This codex is one of the many manuscripts vandalized by Bishop Porphyry Uspensky (18041885), who ripped out the folio with the ending of the vita S. Eudociae Heliopolitanae and the beginning of the vita $S$. Domninae martyris, which is now in his collection in the Russian National Library at St. Petersburg, F.I.636.

8-13. Codices 439-444 in the Hilandar collection contain the months of September to April of the largest South Slav menologium ever compiled, which took Abercius four years to copy. 
8. The colophon of the first volume with the month of September, codex 439 finished in 7131 (1622/3), shows that the menologium was compiled by the monks of Hilandar under the supervision of abbot Hilarion. Abercius refers to the manuscript as a panegyricon, which was the common South Slav term for a menologium since it contains not merely vitae but also festal homilies and eulogies. This codex also suffered from the ravages of Porphyry Uspensky, who tore out the folio with the ending of Symeon Metaphrastes' Vita S. Charitonis confessoris and the beginning of the Vita SS. Gregorii Armeni et sociorum, now in his collection in the Russian National Library, F.I.639.

9. The colophon of codex 440 with the month of October shows that it was finished in the following year $7132(1623 / 4)$.

10. Codex 441 with the month of November was also finished in 7132. In the colophons of both of these manuscripts Abercius mentions the work of the abbot and monks of Hilandar on the compilation of the menologium.

11. Codex 442 with the month of December was finished in the following year $7133(1624 / 5)$ and in the colophon Abercius states that if there is a mistake in a word such as a missing letter or if the orthography of the same word varies in the codex the reader should not to correct it if elsewhere it is correctly written. The claim that he is encouraging the reader to do exactly the opposite, viz. correct the word, is an erroneous interpretation of the passage. He also urges his readers not to mark a passage to be read with wax but to place a marker "as does your father the Greek." In the colophon Abercius calls himself "a monk from Hercegovina." Once again Uspensky has removed a folio, this time with the ending of the Passio S. Eleutherii episcopi Illyrici and the beginning of the Biblical tale of Daniel and Susanna, now in his collection, F.I.640.

12. In the colophon of codex 443 with the month of January finished in $7134(1625 / 6)$ Abercius states he has been using eight manuscripts for the compilation of the menologium.

13. In the colophon of Codex 444 containing the months of February to April, also finished in 7134, he states that the months of May to August have been copied by somebody else, viz. codices 445-446 in the Hilandar collection with the months of May to June and July to August respectively. The name of the scribe of the two codices is unknown and they are undated but must have been finished by $1625 / 6$ because Abercius refers to them as finished. Abercius then says that the supervisor and driving force behind the compilation of the menologium had been abbot Hilarion and that each volume had been based upon seven or eight exemplars and that the monastery had purchased other things which Hilandar did not have. He also expresses his disappointment that he had had no time to illuminate even one initial letter but he had had to copy 255 quires, not to mention the 107 quires of the synaxarium.

14. Codex 9 in the collection of the Orthodox bishopric of Arad, which contains forty-nine entries for movable feasts from the last Sunday after Epiphany until Trinity Sunday, does not have a colophon but a lengthy inscription by hieromonk Anthony, a former hieromonk of the monastery of the Presentation of Our Lady at Gomionica, who states that it was copied for him by Abercius in the hermitage at Karyes in 7134 (1625/6).

15. Five years elapsed before Abercius copied his next manuscript in 7140 (1631/2), a Lenten quadragesimale, in the hermitage at Karyes when Phillip was abbot of Hilandar. He refers to it as a Zlatoust, the Slavonic equivalent for the Greek term Chrysostomicon, literally a book containing homilies by John Chrysostom, but by the sixteenth century at the latest the Slavonic term was used as a general term to denote a homiliary, especially a Lenten quadragesimale. He states that this manuscript together with "the others" meant that he had copied 535 quires. This 
codex too was a victim of Uspensky's habit and one folio with the ending of an unidentified homily for the Saturday after Passion Sunday and the beginning of the Sermo in ramos palmarum et in pullum asini by Sophronius of Jerusalem, in Slavonic - as in some Greek MSS ascribed to Cyril of Alexandria, was torn out and is now in his collection, F.I.633

16. Codex 21 (135) in the collection of the monastery of the Annunciation at Žitomisljić, Hercegovina, contained the Vita Barlaam et Joasaph, the colophon of which shows that it was copied at the hermitage at Karyes in the following year, 7141 (1632/3). The monastery and its collection of manuscripts were destroyed during the Second World War and the number of its folia in unknown.

17. The colophon of an undated seventeenth-century Serbian codex containing a November menaeum in the collection of the monastery of Iviron on Athos states that it was copied at Sotir, the Saviour, by "the sinful and lazy Abercius", while an inscription on the reverse of the last folio reveals that it already belonged to Iviron on Sunday 4 December 7171 (1662). The Saviour was an Athonite cell which was a dependency of St Paul's monastery on Athos founded by Serbs in the fourteenth century and which remained Serbian until the eighteenth century. The manuscript has been ascribed to the Abercius who copied all the other manuscripts but this must remain an unsubstantiated hypothesis until the ductus of scribe of the manuscript has been compared with that of Abercius' other manuscripts.

From the information in these colophons it is known that he came from Hercegovina and since the ductus of the the earliest of his manuscripts of 1614/5 already reveals a skilled hand the codex was clearly not his first attempt at copying, so that it can be concluded that Abercius was born at the latest in the mid 1590s. Since the codex is also the sole manuscript which he donated, it is possible that it was an expression of his gratitude for having been tonsured or trained as a scribe, or both, at the monastery of the Annunciation at Dobrun in south-eastern Bosnia, which is not far from Hercegovina. By the following year, 1615/6, he was at St Nicholas' monastery in the Ovčar Gorge near Čaček in western Serbia, a hundred or so kilometres east of Dobrun. From there he moved to the hermitage of St Sabas of Serbia about eight kilometres from the monastery of the Deipara Euergetis by the Studenica, a tributary of the Ibar, and it was there that he copied the next two manuscripts in 1617/8 and 1618/9. Two years later in 1620/1 he was on Athos in St Sabas' hermitage, a dependency of Hilandar at Karyes, where he remained for at least the next twelve years.

It has been claimed that at least three other scribes worked at the hermitage during that period but two of the scribes were definitely not there and the third, an anonymous scribe who in $7135(1626 / 7)$ copied a synaxarium for the months of September to February for hieromonk Joannicius at Karyes in "the cell of Hilandar", may perhaps not have been there since in no single manuscript in the Hilandar collection associated with the hermitage is it called "the cell of Hilandar", cf. "the cell of St Sabas", "the hermitage of St Sabas", "the tower and hermitage of St Sabas" and "the tower of St Sabas". Abercius does refer to the hermitage as "the tower of Hilandar" at Karyes (№ 7) and "the tower" at Karyes (№№ 8, 10-11 and 15), while in one (№ 9) he calls it "the pillar" at Karyes and in the last one (№ 16) "the keep, that is the pillar" at Karyes, but never "the cell". The claim that the anonymous scribe who had copied the two volumes of the menologium with May to June and July to August at the same time that Abercius was copying his volumes was working with him at the hermitage is unlikely in view of the confusion in his work: the entry for 1 July is found among the entries for June 30 in codex 445 so that codex 446 with July to August begins with the entry for 2 July, while the entry for 25 July precedes the entry for 20 July and the entry for 12 August is appended to that for August 31, all 
of which mitigates against the idea that the two scribes were working together in close cooperation. It thus remains uncertain whether any other scribe was working at the hermitage at the same time as Abercius.

It has been claimed that Abercius in accordance with the current literary fashion wrote acrostic colophons in syllabic verse, indeed, it has even been asserted that metrical poetry was his lifelong vocation and that his verses have a definite literary-historical significance. It is true that in his first two MSS Abercius did not sign his name in the colophons but wrote a seven-line text with an acrostic containing his name and in both cases he referred to the lines as "verses", ñò 'õ', but the claim that he composed metrical poetry is untenable since the "verses" are not his but have been taken from a Bulgarian translation of an anonymous Greek collection of gnomes.

Without any doubt Abercius' greatest achievement was to copy most of the largest extant South Slav menologium. In the colophon of the December volume (№ 11) he states that he has taken the entries for each volume from seven or eight old MSS, in that of January (№ 12) he mentions that he has used eight, but in his final colophon of February-April (№ 13) he specifies that seven of the MSS used belonged to Hilandar and entries not in them had been purchased from elsewhere. These statements have been misconstrued to mean that he was striving to obtain a critical text by an analysis of several exemplars and it has even been considered that he may have consulted Greek texts. It is true that Abercius occasionally gives explanatory glosses on

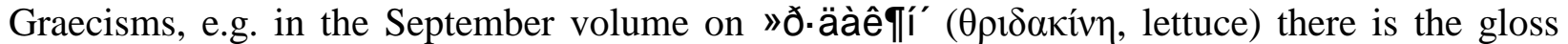

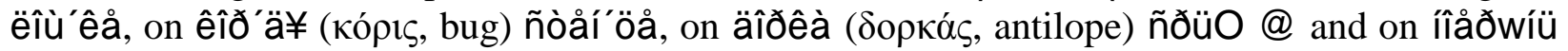

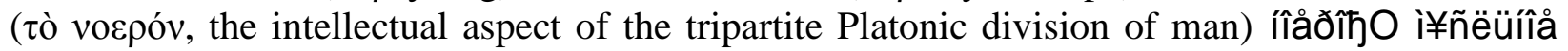
ãë $\neg$ U. As a result of his prolonged stay on Athos Abercius must almost certainly have known at least some demotic, nevertheless, these glosses provide no evidence for his consultation of Greek texts since they are all found in earlier September menologia including one copied in the midfifteenth century by former abbot Joseph of Hilandar, which was still at Hilandar when Abercius was copying the menologium, but which was later given to the monastery at Orahovica. Abercius did not in fact correct or revise the texts by consulting Greek originals or even by comparing several Slavonic manuscripts.

It is not even certain to what extent Abercius was himself responsible for the selection of the contents of the menologium. Clearly he had to seek Hilarion's approval for the inclusion of an entry but it is clear that he was also being instructed to include entries against his will, since occasionally in a gloss he expresses misgivings about the authenticity of an entry. There are, for instance, two entries for the feast of St Nicholas of Myra on 6 December, the Vita S. Nicolai Sionitae prope Myram followed by Symeon Metaphrastes' Vita et conversatio et singularis miraculorum narratio miraculis clarissimi Nicolai archiepiscopi Myrae in eparchia Lyciorum. The first of these was originally the vita of Nicholas, abbot of Sion near Myra, who became bishop of Pinara in Lycia but was later confused with Nicholas of Myra and his Greek vita was altered accordingly. This version was translated into Slavonic and Abercius, rightly considering that its account of St Nicholas was spurious, added a gloss at the foot of the folio with the passage recounting how Nicholas sacrificed bulls to appease divine wrath which had visited a plague upon the people of Myra: İå iíp á¥U 'ñò 'íà ñ·å ñëî̉ $B$, and at the foot of the folio where

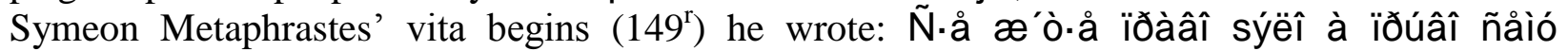
iåäîñoî́'î $\neg T ђ$. Or again, the entry for the feast of St Mark the Apostle on 25 April is the apocryphal Martyrium S. Marci. Abercius realised its true nature and at the top of the folio with the passage in the middle of the vita where the pagans are preparing to arrest St Mark he noted in a gloss: Òî̀ å ãëîâi íãnëDàêî ' íåâhðîî. The answer to the question as to why he was 
including such entries in the menologium and is to be found in one of his glosses in the first volume: September 14 is the feast of the Exaltation of the Holy Cross, for which six entries are given, the last of them being Menander Protector's Narratio de apparitione et inventione Crucis, the authenticity of which Abercius rejected as two of his glosses reveal: beside the passage describing how a Jew named Judas revealed the location of the True Cross to Empress Helena he wrote: lå ëúæ', åoåò'æå, làêàòå wáohòü, à íå ò¥", while beside the passage describing how Judas drove out Satan, who complains: Äđåâë áî àç lóäîp ñúòâîo’a ëpäåiü ñúãoýø'ò'

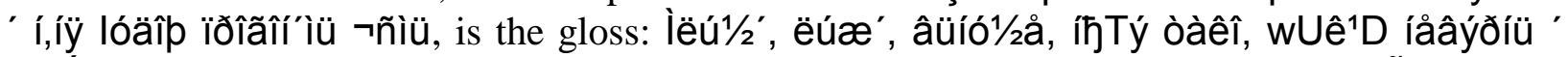

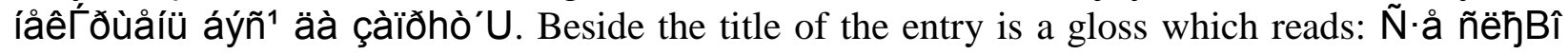
í†Tý 'ñò 'íî́, íå áýøå çäåa 'ãóiàíà äàBちøàãNîJ 'çâDî, ' íå çìaa ñ·å wUìhí'ò' đàD " ÿZâ¥ \{ "This homily is not veracious, had it not been for the abbot here giving me the exemplar, and I dared not exclude this because of punishment". Whether the word for punishment, ÿçâà, a beating, is meant literally is uncertain, but clearly Abercius risked some form of punishment by abbot Hilarion if he omitted an entry which the abbot had instructed him to include because of his misgivings about its authenticity, which means that it remains uncertain to what extent Abercius was himself responsible for the choice of entries for the menologium.

Between 1614/5 and 1625/6 Abercius copied fourteen codices and then between 1631/2 and 1632/3 two more, but there has been some confusion as to the total volume of his work. Abercius himself made two statements on the subject. In the colophon of the last volume of the menologium which he copied in 1625/6 (№ 13) he states that "the above-mentioned scribe" had written 355 quires of the menologium and 107 quires of the synaxarium, viz. 462 quires or 3696 folia. In the colophon he had already mentioned the other scribe of the menologium but this reference to "the above-mentioned scribe" can only refer to Abercius himself since the number of folia in the synaxarium (№№ 5-7) is 860 and in the volumes of the menologium which he had copied (№o 8-13) 2841, viz. 3701 folia or 462 quires and 5 folia. In his quadragesimale of 1631/2 (№ 15) he states that he had "copied this Chrysostomicon and also the others”, in all 535 quires, viz. 4280 folia. The number of folia in the synaxarium and his part of the menologium (№№ 5-13) is 3701 and in his homiliary of 1625/6 (№ 14) it is 577, viz. 4278 folia or 534 quires and 6 folia, in other words "the others" refers to all the previous MSS which he had copied at Karyes, which in turn means that all of the codices which he copied at the hermitage between 1620/1 and 1631/2 (№№ 5-14) have survived and hence the claim that he must undoubtedly have copied more MSS between 1626 and 1633 is incorrect. The number of folia in the Vita Barlaam et Joasaph (№ 16), which he copied at Karyes in 1632/3, is unknown but can be roughly estimated at about 260 since that is the average number of folia in five manuscripts with the text. This evidence also shows that if he did copy the Iviron codex at the Athonite cell of the Saviour he must have done so after he had copied the MSS at the hermitage at Karyes. The total number of folia of the MSS which he copied at Karyes (№№ 5-16) including the Uspensky folia is thus 5089, which together with the 1082 folia of the previous four MSS gives a grand total of 6171 folia, which will obviously increase if he copied part or all of the Iviron codex (№ 17).

Abercius' statement that he had "copied this Chrysostomicon and also the others" has been misunderstood to mean that he copied more Chrysostomica, the number of pages of which has been estimated to be about 3200, viz. 1600 folia. This estimate would mean that he copied over 15,500 pages, although for no obvious reason it has been claimed that the overall total is "about eighteen thousand pages", viz. 9000 folia. In fact all that can be said is that the total number of folia which he copied is at least 6171. The fact that Abercius kept an accurate account of the number of quires which he had copied has been considered "pedantic", but the fact that he 
copied nothing for some five years (1626/7-1630/1) points not so much to a pedant as to someone who for six years (1620/1 to 1625/6) had obediently copied 4278 folia, an annual average of 713 per year, but had not particularly enjoyed doing so. Not for nothing did he complain in the colophon of the last volume of the menologium which he copied (№ 13) that he had not had time to illuminate any of the initial letters.

The date of his death is not recorded but an attempt to calculate it has been made on the basis of data contained in the register of the principal events at the hermitage at Karyes in codex 518 of the Hilandar collection, which covers the period from 1645 to 1836 . In 1645 Dionysius, the superior of the hermitage at that time, began new lists of those to be commemorated at the hermitage by copying names from previous diptychs and leaving folia blank for the addition of more names. There are folia for archbishops, bishops, hieromonks, monks, priests, nuns and for others not included in any of these categories. The names of the hieromonks have been written by Dionysius in three columns and the name Abercius occurs as the second name in the very first column. It has been concluded that since Dionysius compiled the lists of names in 1645 and Abercius' name occurs at the beginning as the second name on the list of the deceased and again a little later on he must have died in 1645 or 1646 . This conclusion is unsafe since the name Abercius does not occur twice but no less than five times, the first four times written by Dionysius. Clearly Dionysius was not mindlessly repeating the names of a few monks time after time and the occurrences obviously refer to different monks with the same name which he had found in the diptychs which he was copying. There is thus absolutely no certainty that any of the references to Abercius refers to the scribe of the menologium. Indeed the reverse is the case since all five cases involve hieromonks, whereas not only does Abercius refer to himself as a monk and not as a hiermonk (№ 11) but hieromonk Anthony, formerly of Gomionica, for whom Abercius copied the homiliary in 1625/6, also refers to him as a monk and not as a hieromonk (№ 14) and since the name Abercius does not occur in the list of monks, as opposed to hieromonks, copied by Dionysius into the register, the inference must be that Abercius was still alive in 1645 . Be that as it may, rather than giving his dates as mid 1590s-after 1645, it is safer to give fl. 1614/5-1632/3.

To sum up, Abercius was an obedient monk who copied the menologium in accordance with the instructions of his abbot even when he disagreed about the inclusion of a particular entry. Indeed, the extent to which he himself chose the entries to be included is unknown and the claim that he compiled the menologium as opposed to copying it remains unproven. Although it is sometimes referred to as Abercius' menologium, he himself made it quite clear that the driving force behind the project was abbot Hilarion of Hilandar (1622/3-1627/8) so that it could with equal justice be called Hilarion's menologium. Abercius several times states that the monks at Hilandar contributed to it under the supervision of Hilarion and also once that the monastery met the expenses incurred by obtaining texts which were not in its collection. For these reasons the most appropriate name for the largest South Slav menologium is "The Hilandar Menologium". Abercius may have played a more modest role in the actual selection of the entries to be included than that with which he has hitherto been credited, but despite this it remains a fact that without his selfless diligence and painstaking and unremitting toil over a period of some four to five years the menologium would not exist. 